\title{
THE RED-MED RAILWAY PROJECT A SERIOUS COMPETITOR TO THE SUEZ CANAL FOR CARGO CONTAINERS?
}

\author{
Salem Y. Lakhal \\ Université de Moncton, Canada \\ E-mail: salem.lakhal@umoncton.ca \\ Souad H'Mida \\ Université de Moncton, Canada \\ E-mail : souad.hmida@umoncton.ca
}

Submission: $23 / 01 / 2017$

Revision: 04/02/2017

Accept: 10/02/2017

\section{ABSTRACT}

Israel and China have finalized a project plan initiated in 2012. This project received the green light from Israeli cabinet in March 2014. With this venture, China will build a cargo railway line connecting the port of Eilat in the Red Sea to the ports of Ashdod and Haifa on the Mediterranean coast in Israel. This project will be a shipping alternative to the Suez Canal. This statement is the corner stone of this paper and considered a hypothesis to be verified within this paper. The methodology used is based on the concept of "market position." The main conclusion, theoretically, the Red-Med railway could be an alternative to the Suez Canal for the 4,000 TFE Vessels containers transportation as far as costs are concerned. However, other issues, such as terrorism incidents, the security in the Suez Canal and the risk of its shutdown, must be considered too.

Keywords: Suez Canal, Red-Med Sea Railway Line, Israel, Egypt, container transport. 
DOI: 10.14807/ijmp.v8i3.619

\section{INTRODUCTION}

Establishing a railway line linking the Red Sea and the Mediterranean Sea is considered to be of strategic importance for Israel because it will serve as an alternative to the Suez Canal. For Israeli Prime Minister Benjamin Netanyahu, the strategic importance of this project is the possibility of linking Israel to the increasing and emerging economies of countries such as China and India (LEVITT, 2014).

Prime Minister Netanyahu states: "In the coming decade, new powers will arise and the State of Israel must create vital interests from a national strategy pointof-view. We have the ability to create an alternative transportation route that bypasses the Suez Canal - this is an insurance policy. Israel must become a continental land crossing route and create great power interests." (ANONYMOUS, 2012; SCOTT, 2014; ISRAELI-GOVERNMENT, 2012).

Based on thee geo-political picture in the Middle East, Israel continues to work on maintaining its security, its economic independence, and its resilience (LAKHAL, 2017). To ensure continued supply lines that are not interrupted by regional crises, Israel is working to develop and create convenient and fast shipping and supply routes, which connect the Mediterranean Sea to the Red Sea and provide access to the greater Asian oceans.

In this context, Israel imports raw materials, energy, and goods from countries in Asia and Africa, which is accomplished by vessels navigating through the Suez Canal, and, from there, to the ports of Ashdod and Haifa. However, there is no guarantee that the Suez Canal will remain open due to the failure of the Egyptian Government to impose its authority on the Sinai Peninsula since the coup on July 3 , 2013.

In the event of a Suez Canal closure, the port of Eilat is a strong asset for Israel. The alternative route of going around Africa to enter the Mediterranean Sea is very expensive, while the port of Eilat could be a tangible alternative, which allows Israel to maintain its independence and not stay linked to its neighbours (Figure 1). 


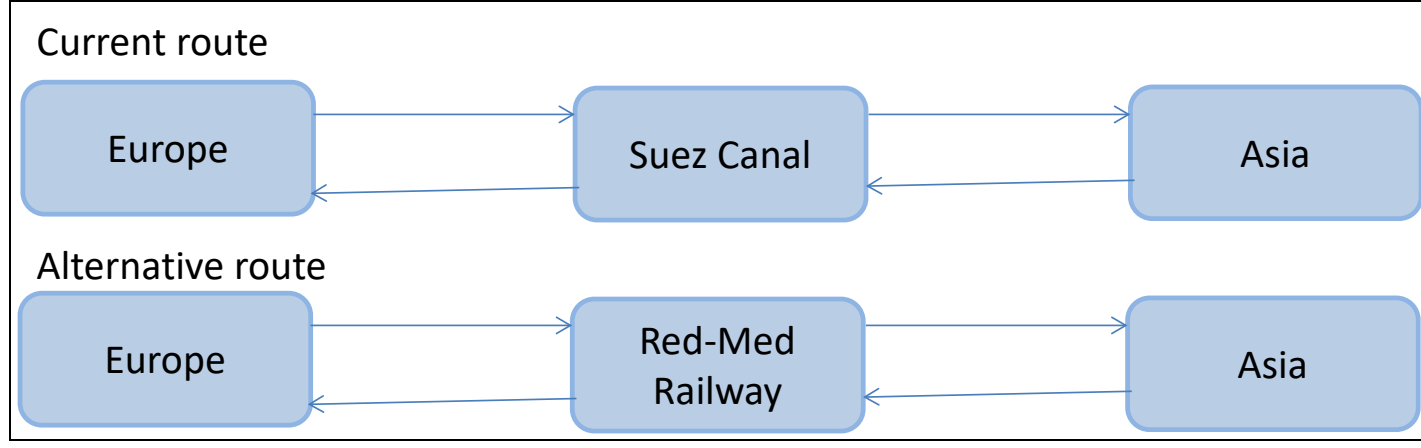

Figure 1: Current shipping through the Suez Canal route versus the alternate route via the Red-Med railway project.

Transportation from Eilat to the centre of Israel is not sophisticated, currently does not allow for a fast, large-scale transport of containers and goods. According to the Israeli point of view, it is not necessary to watch events in Egypt to understand that the port of Eilat is a strategic asset to Israel and to recognize that establishing a rail line from the port to the centre would increase its value.

According to Verisk (2015), the ongoing crackdown in Egypt against the political opposition would increase the potential for more frequent terrorist attacks. Whilst the government of President Abdul Fatteh Al-Sisi's hard-line security stance has reduced the likelihood of large-scale violent protests for the medium term, terrorist incidents have become more frequent and ambitious under Al-Sisi's time in office - including in Egypt's major urban hubs.

Over the past three years, a shift towards more frequent and widespread terrorist attacks have been registered as indicated in Figure 2 and 3. One-hundredand-thirty terrorist attacks were recorded over the 2014/15 period (VERISK, 2015). This significant increase marks a more-than fourfold increase in the number attacks on the corresponding 2013/14 period (when there were 29 terrorist attacks in total). There were no recorded terrorist attacks in the corresponding 2012/13 period. The chaotic situation in Egypt gives compelling reason to Israel to go forward with the Red-Med Railway project. 
INDEPENDENT JOURNAL OF MANAGEMENT \& PRODUCTION (IJM\&P)

http://www.ijmp.jor.br

v. 8, n. 3, July - September 2017

ISSN: 2236-269X

DOI: 10.14807/ijmp.v8i3.619

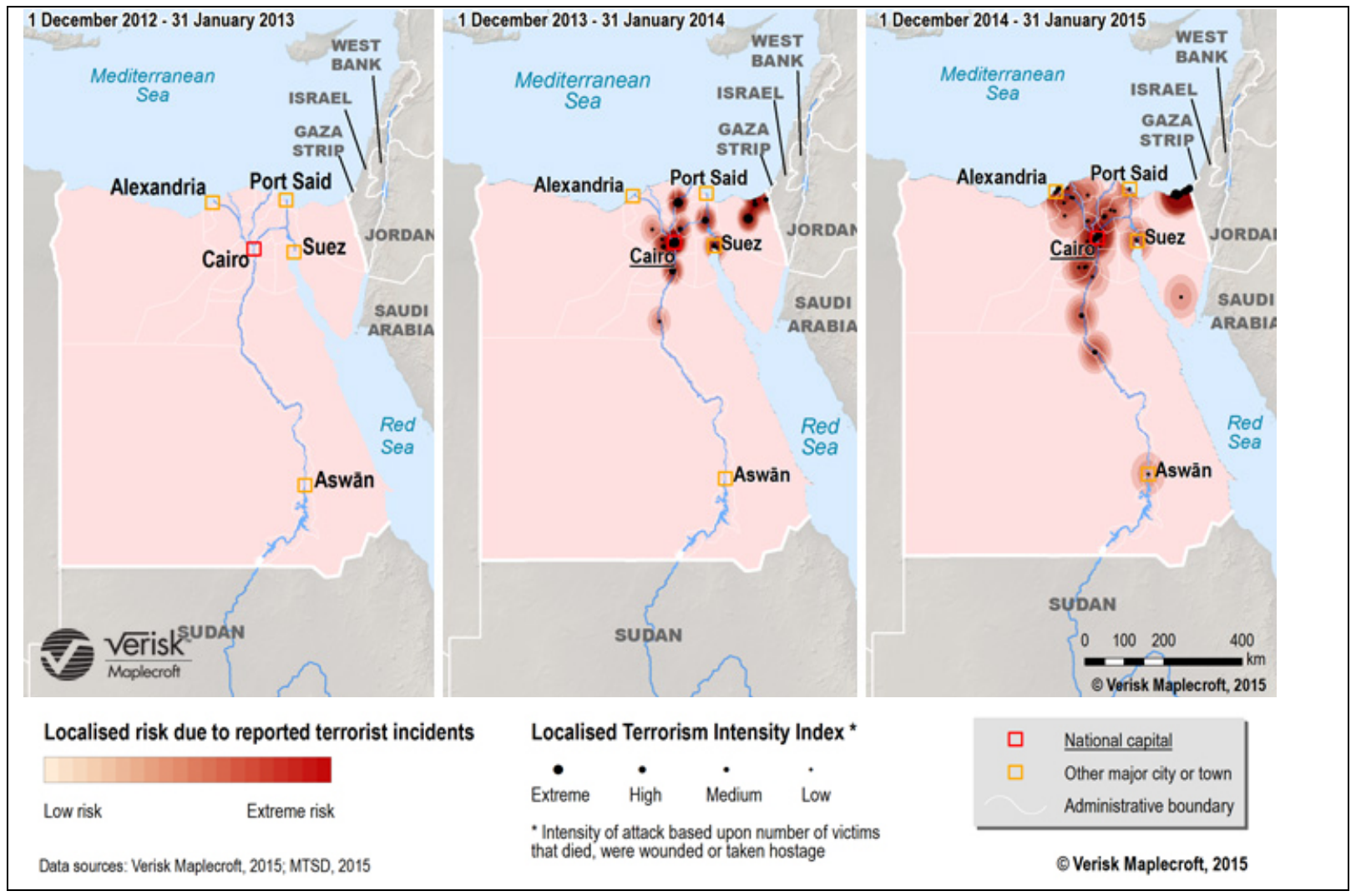

Figure 2: The increasing terrorism attack in Egypt

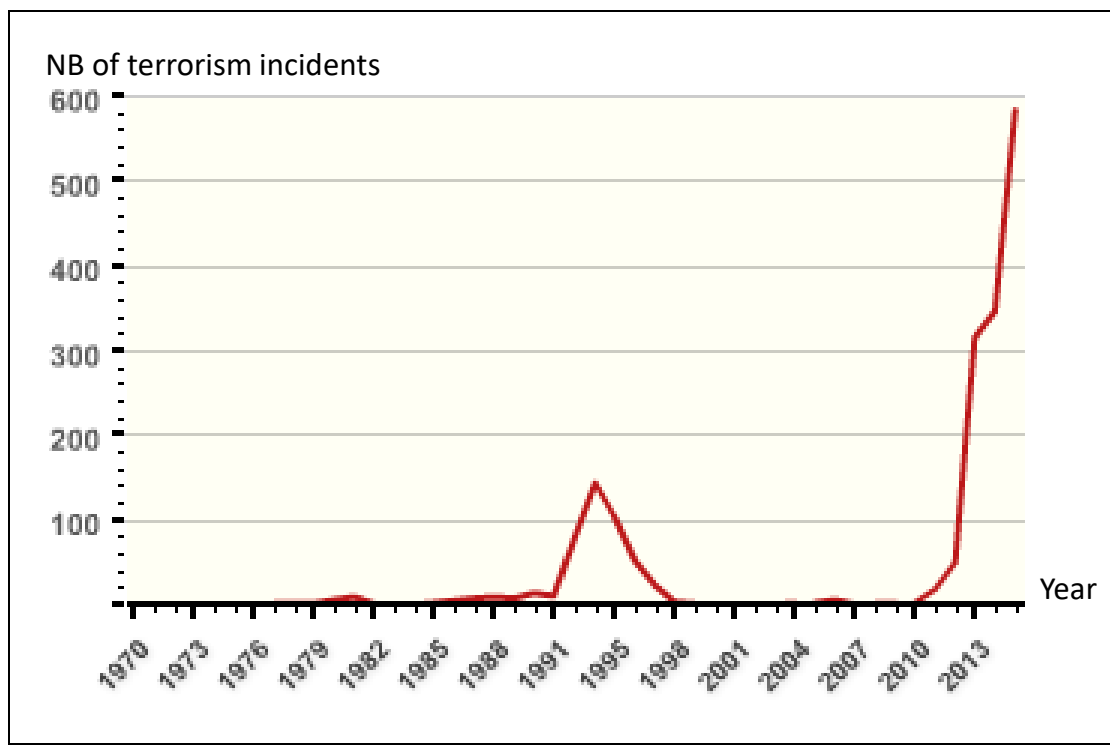

Figure 3: The evolution of number of terrorism incidents in Egypt Source: https://www.start.umd.edu/gtd/search/Results.aspx?country=60

\section{LITERATURE REVIEW}

Despite some press articles related to the Red-Med railway project, there are a very few academic studies associated with bridging Asia to Europe by land transportation. 
INDEPENDENT JOURNAL OF MANAGEMENT \& PRODUCTION (IJM\&P)

http://www.ijmp.jor.br

v. 8, n. 3, July - September 2017

ISSN: 2236-269X

DOI: 10.14807/ijmp.v8i3.619

Looking for an alternative to the Suez Canal become an issue for Israel after the closing of the Suez Canal during the Sinai Campaign in 1956 and again after the June War of 1967 (GRADU, 1977).

The State of Israel was in a position to use the Negev land bridge as an alternative to the Canal, whereby freight could move between the Red Sea and the Mediterranean Sea. According to Gradu (1977), immediately upon the 1967 closure of the Canal, representatives of Israeli economic concerns began to look into the possibility of setting up such route.

Consequently, in 1970, a land bridge was established by the Israeli shipping line, Zim, to provide cargo service between Ashdod and the port of Eilat. Simultaneously, a 42-inch oil pipeline with a capacity equal to 60 million tons per year was laid via the Negev from Eilat to Ashdod.

The use of the continental bridge for cargo traffic and the pipeline for the oil transportation gave viability to the opportunity for a railway link between port of Eilat and the ports on the Mediterranean Sea. As container cargo increases, a railway project could be a strong alternative for this kind of freight.

An economic concern, Gradu (1977), reported that the Israeli Transport Ministry conducted a calculation of the difference in costs between the route around Africa and the continental bridge and found that despite several bulk transfer points, a large percentage of the cargoes could be transported at lower cost via a continental.

The Red-Med Railway could have an important historical dimension in the eyes of some Israelis. For example, Schlegel (2013) points to the Bible where God, through the prophet Ezekiel, says, "This is Jerusalem; I have placed her in the center of the nations, with countries round about her" (EZEK. 5:5).

Schlegel adds that Canaan-Israel is a narrow strip of land from the Mediterranean Sea to the Jordan River is 45 miles -sitting at the center of three continents: Asia, Africa, and Europe. The Israeli geographic position gives the country great importance as a land-bridge between the three continents, particularly between the two most ancient cradles of civilization - the Mesopotamia and Nile River basins. 
Historically, Canaan-Israel has been coveted by empires in Asia, Africa, and Europe for this geo-political importance as a commercial and military hub connecting the continents. For Schlegel (2013), "The Sovereign God has chosen this land at the "center of the nations" to work His purposes for mankind Economy".

The research questions are:

(1) Could the Red-Med Railway provide a viable alternative to the Suez Canal for container traffic between Europe and Asia?

(2) Is the Red-Med Railway cost competitive compared to Suez Canal?

(3) Does the Red-Med Railway, as a possible complementary route to Suez, represent an opportunity to improve responsiveness and adaptability in supply chains?

The methodology used is represented in Figure 4, and it is the one used by Notteboom (NOTTEBOOM, 2012; NOTTEBOOM, 2011), based on the concept of "market position." This is made operational by analyzing and comparing transit times and generalized costs on a set of origin-destination relationships.

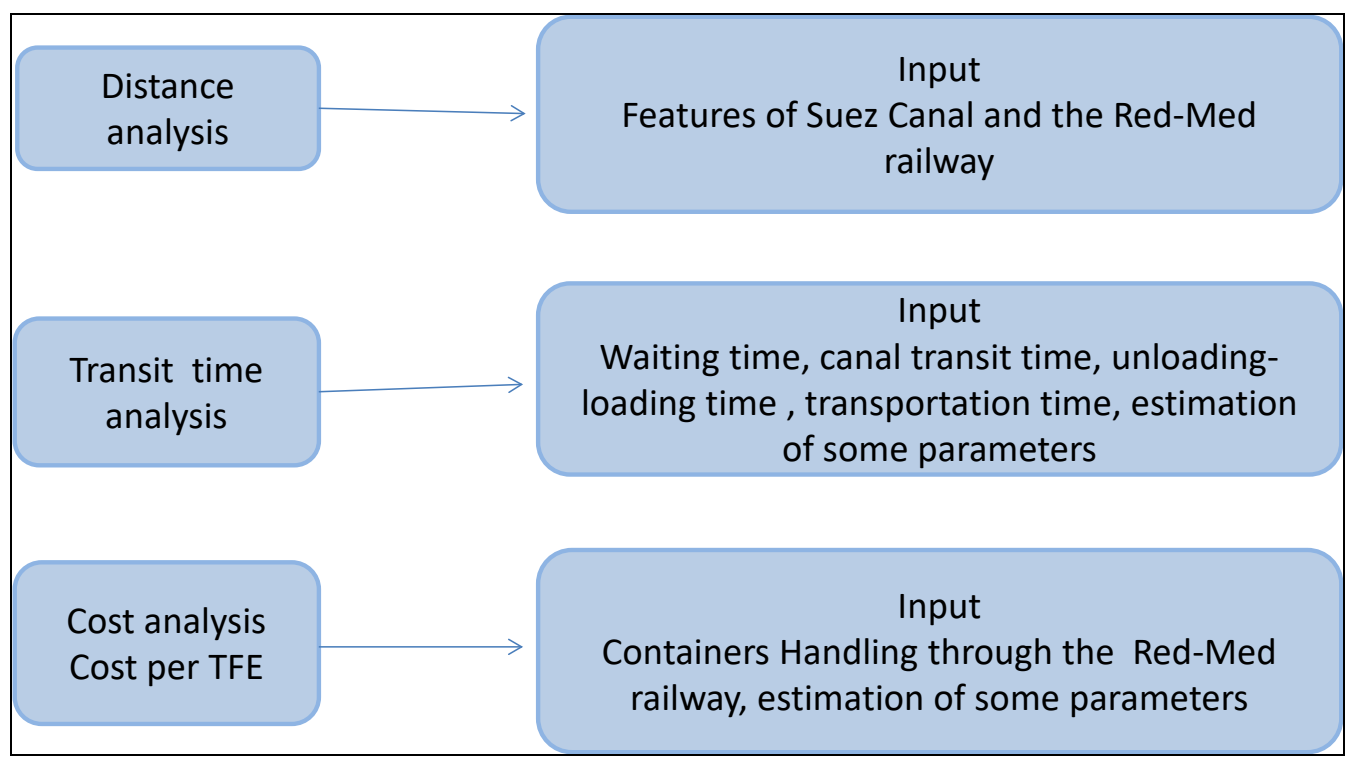

Figure 4: Methodology used

The paper is structured as follows: section 3 presents the logistic analysis of the transfer of vessels cargo charged by 8000 TFE (twenty feet equivalent) containers. Section 4 develops the competitive costs between the Suez Canal and the Red-Med railway. Section 5 draws up a set of conclusions. 


\section{RED-MED RAILWAY AS AN ALTERNATIVE TO THE SUEZ CANAL FOR CARGO FREIGHT}

The map in Figure 5 indicates the principal characteristics of the Red-Med railway project; some of these characteristics will be discussed later. On the other hand, the investigation on the relevant features of the Suez Canal to the Red-Med project are represented on Figure 6. In 2014, more than 38 million TFE containers were shipped by the Suez Canal (see Table $1 \& 2$ ).

\subsection{The determination of the transit time through the Suez Canal}

The transit time from Port Said to Suez (southbound convoys) is between 14 and 16 hours, with the vessels arriving in a minimum of six hours before the transit time (EL-SHARKAWY, 2016). Then, between 20 and 22 hours are required to ship cargo through the Suez Canal.

The transit is organised by convoys in both directions. For example, convoys may begin at 0100 hours up to 0500 hours; therefore, the time of arrival at anchorage is 1900 hours. Vessels arriving at 1900 hours to 2100 hours may join the convoy but there is a surcharge of three percent (3\%) of canal dues. Vessels arriving at 2100 hours to 2200 hours may join the convoy with an additional five percent (5\%) of Canal Transit Dues.

Consequently, if a vessels misses the time limit window of arrival at anchorage and if it does not want to pay the surcharge, it must wait until the next convoy commences at 0700 hours to 0900 hours (EL-SHARKAWY, 2016). In this case, the vessel will have to wait six more hours, making the total transit time between 26 to 28 hours.

For convoys taking the south/north direction from Suez to Port Said (northbound convoy), there is only one convoy, which commences from 0500 hours to 1000 hours. The transit time is between 12 to 14 hours (LETH, 2016). The arrival time is 0200 HRS with a surcharge payment required varying between three percent (3\%) to ten percent (10\%) of the normal transit dues with a maximum between 7,000 to 20,000SDR (Special Drawing Rights) with 1SDR equal to 1.5USD (IMF, 2016). Vessels arriving after 0700 hours must wait 19 hours for the next convoy. For the northbound direction, the transit time could be between 15 and 37 hours. 


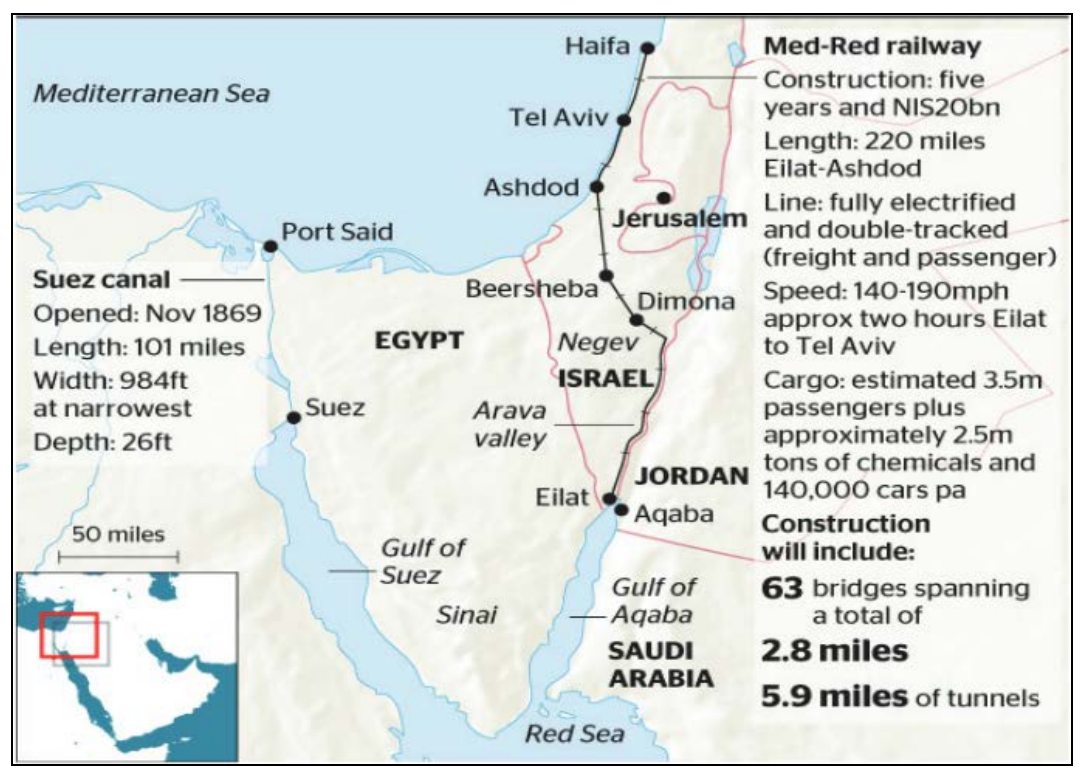

Figure 5: The Red-Med railway as an alternative to the Suez Canal

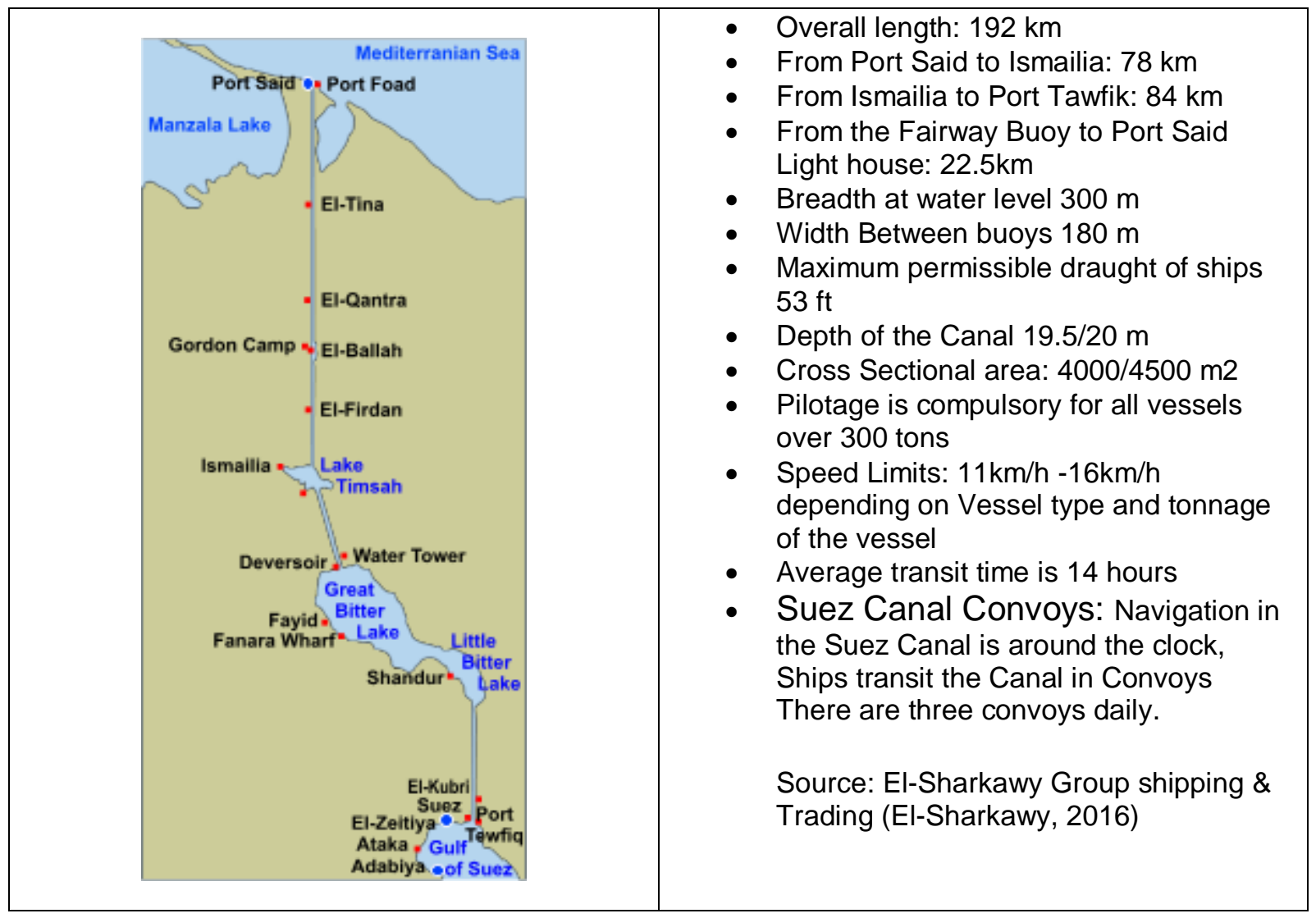

Figure 6: The main Suez Canal features 
INDEPENDENT JOURNAL OF MANAGEMENT \& PRODUCTION (IJM\&P)

http://www.ijmp.jor.br

v. 8, n. 3, July - September 2017

ISSN: 2236-269X

DOI: 10.14807/ijmp.v8i3.619

Table 1: Evolution of the nautical characteristics of the Suez Canal.

\begin{tabular}{|c|c|c|c|c|c|c|c|c|c|}
\hline & Unit & 1869 & 1956 & 1962 & 1980 & 1996 & 2001 & 2010 & 2015 \\
\hline Width at $11 \mathrm{~m}$ depth & $\mathrm{m}$ & -- & 60 & 89 & $160 / 17$ & $180 / 20$ & $195 / 215$ & $205 / 225$ & $205 / 225$ \\
\hline Maximum draft of vessels & feet & 22 & 35 & 38 & 53 & 58 & 62 & 66 & 66 \\
\hline Overall length & $\mathrm{km}$ & 164 & 175 & 175 & 189.8 & 189.8 & 191.8 & 193.3 & 193.3 \\
\hline Doubled parts length & $\mathrm{km}$ & - & 27.7 & 27.7 & 77 & 77 & 79 & 80.5 & 113.3 \\
\hline Water depth & $\mathrm{m}$ & 8 & 14 & 15.5 & 19.5 & 21 & 22.5 & 24 & 24 \\
\hline
\end{tabular}

Table 2: Traffic Containers through the Suez Canal from 2000 to 2014 (No. of TEU's by Ship Status)

Source: the Suez Canal Authority: www.suezcanal.gov.eg/TRstat.aspx?reportld=8

\begin{tabular}{lrrr}
\hline Year & Laden & Ballast & Total \\
\hline \hline 2000 & $12,109,374$ & $1,922,349$ & $14,031,723$ \\
\hline \hline 2001 & $12,331,156$ & $1,820,251$ & $14,151,407$ \\
\hline \hline 2002 & $13,779,935$ & $2,111,116$ & $15,891,051$ \\
\hline \hline 2003 & $15,937,527$ & $2,948,329$ & $18,885,856$ \\
\hline \hline 2004 & $18,591,937$ & $3,738,330$ & $22,330,267$ \\
\hline \hline 2005 & $20,567,661$ & $4,689,745$ & $25,257,406$ \\
\hline \hline 2006 & $22,915,716$ & $5,636,892$ & $28,552,608$ \\
\hline \hline 2007 & $26,301,928$ & $7,838,735$ & $34,140,663$ \\
\hline \hline 2008 & $27,772,184$ & $8,073,246$ & $35,845,430$ \\
\hline \hline 2009 & $24,746,307$ & $5,023,627$ & $29,769,934$ \\
\hline \hline 2010 & $29,589,864$ & $7,184,913$ & $36,774,777$ \\
\hline \hline 2011 & $31,653,579$ & $6,988,327$ & $38,641,906$ \\
\hline \hline 2012 & $31,601,291$ & $6,115,979$ & $37,717,270$ \\
\hline \hline 2013 & $32,270,166$ & $5,892,106$ & $38,162,272$ \\
\hline
\end{tabular}

Source: Author's calculation based on data Suez Canal Authority.

Note: the traffic containers statistics are no more available in the Suez Canal website (verified on 2106 Dec. 15)

\subsection{The determination of the transit time through the Red-Med railway}

To determine the transit time through the Red-Med railway, variants to consider are the times to:

- unload the containers from the vessel;

- load the containers on the train;

- transport the containers to the other coast; and

- load the containers on another vessel to continue its route.

For example, if the containers originate in Eilat, the estimate includes the time needed to unload containers from the vessel, transfer the containers to the Ashdod 
port, and load them to another vessel to continue the voyage to Europe. For most competitors, this time allows the comparison with Suez Canal to the Red-Med project.

\subsubsection{Vessel unloading and train loading time}

Considering an 8,000-container vessel and four cranes on the port deck working at the same time to discharge the vessel, the containers are taken from the vessel and put directly on the train wagons. Each wagon can transport four TFE containers. A train with 100 wagons could transport 400 containers in one voyage.

Depending on the efficiency of the cranes, it is possible to unload up to 50 containers in one hour. In this study, we chose a conservative estimate of one crane handling 40 containers in an hour (DUCRUET et al., 2014). Therefore, the time required to load 100 train wagons is 2.5 hours; considering some contingency factors, the time is rounded up to 3 hours loading time.

In connection with this project, the newspaper Yediot Aharonot published an article by attorney Yair Hazan six days after the outbreak of the Egyptian revolution, confirming that "port of Eilat turned to be a strategic asset during the unrest situation in Egypt."

\subsubsection{Train transportation time from the Red Sea to Mediterranean Sea}

The railway route between Eilat and Ashdod is 220 miles (SCOTT, 2014; UNISHIPING, 2016), which is the equivalent of $354 \mathrm{~km}$. There is no indication of the Red-Med railway class compared to the United States; the Federal Railroad Administration has developed a system of classification for track quality. The class of a section of track determines the maximum possible running speed limit. Most mainline tracks in the United States own Class 4 tracks allowing a maximum speed equal to $60 \mathrm{mph}(97 \mathrm{~km} / \mathrm{h})$ (WIKIPIDIA, 2016).

In this analysis, the average speed is $75 \mathrm{~km} / \mathrm{h}$, which is higher compared to the average train speed in Europe (RFI, 2014). According to MATHIOT (2009), former France President Sarkozy declared in 2008 that the average speed was $13 \mathrm{Km} / \mathrm{h}$. For long distances, average speeds differ in other areas. For instance between FranceChina $(12000 \mathrm{~km})$, it takes 10 days at an average speed of $50 \mathrm{~km} / \mathrm{h}$ (Amedeo and Nodé-Langlois, 2009); and, for a 13000 km trip between East China to Madrid (Spain), it takes 22 days at an the average speed of $24.6 \mathrm{~km} / \mathrm{h}$ (RFI, 2014). 
Therefore, for the Red-Med railway, $354 \mathrm{~km}$ could take between 4.5 to 5 hours, which is an optimistic assumption. For this analysis, it would take 5 hours to go to Ashdod from Eilat and another 5 hours to return.

Scott (2014) reported that Red-Med passenger railway could reach a speed of 140 to $190 \mathrm{mph}$. Of course, the speed of a freight train is quite different to a passenger train; these parameters must be accurate as they are one of the cornerstones of the calculation. Troche (2005) studied the question and calculated the difference between a (i) passenger train used as a freight train and a (ii) wagon freight train. The speed of the latter is inferior when compared to the speed of the former. Furthermore, a speed of a $120 \mathrm{~km} / \mathrm{h}$ for a wagon freight train is considered high (Table 3).

Table 3: High-speed rail freight

\begin{tabular}{|l|l|l|}
\hline \multicolumn{1}{|c|}{ Denomination } & \multicolumn{1}{|c|}{ Maximum speed } & \multicolumn{1}{c|}{ Predominant vehicle } \\
\hline High-speed rail freight & $>200 \mathrm{~km} / \mathrm{h}$ & $\begin{array}{l}\text { Modified high-speed passenger trains } \\
\text { Fixed train-sets }\end{array}$ \\
\hline Semi-high-speed rail freight & $140-200 \mathrm{~km} / \mathrm{h}$ & $\begin{array}{l}\text { Both vehicles based on passenger train } \\
\text { concepts and further developed freight } \\
\text { wagons } \\
\text { Fixed train-sets as well individual freight } \\
\text { wagons }\end{array}$ \\
\hline Conventional rail freight & $<120(140) \mathrm{km} / \mathrm{h}$ & Conventional freight wagons \\
\hline \multicolumn{2}{|c|}{ Source: (Troche, 2005) }
\end{tabular}

\subsubsection{Train unloading and vessel loading}

When the train arrives in Ashdod, the containers will be unloaded and reloaded directly on another vessel waiting. This operation will take three hours, which is the same time to unload the vessel and load the train. After that, the train will be loaded with containers from another vessel waiting in the port, taking 3 hours. Once loaded, the train will return to Eilat in 5 hours.

After returning to Eilat, the train will be unloaded ( 3 hours), and the cycle will begin again. The complete cycle takes a total of 22 hours (see Table 4).

Table 4: Train's time cycle to transfer a container load between Eiliat-Ashdod

\begin{tabular}{|c|c|c|c|c|c|c|c|c|c|c|c|c|c|c|c|c|c|c|c|c|c|c|}
\hline NB & $\mathrm{Hol} 1$ & 2 & 3 & 4 & 5 & 6 & 7 & 8 & 9 & 10 & 11 & 12 & 13 & 14 & \begin{tabular}{l|l}
15 & 1 \\
\end{tabular} & 16 & 17 & 18 & 19 & 20 & 21 & 2 \\
\hline & \begin{tabular}{|l|} 
Train \\
\end{tabular} & & & & & & & & & & & & & & & & & & & & & \\
\hline & $\mathrm{t} 1$ & & & & 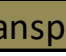 & ort T & & & & load & & Loa & $\mathrm{ad}$ & & rans & $s p$ & t ( & $\mathrm{drn}$ & & & 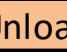 & \\
\hline
\end{tabular}

If that work starts at zero hour, after three hours, train1 leaves for Ashdod and train2 starts loading, and so on. Seven trains will load before train1 returns after 21 hours and it takes 22 hours to load the 7 trains. Then, train 1 has to wait one hour, before begin loading again. 
INDEPENDENT JOURNAL OF MANAGEMENT \& PRODUCTION (IJM\&P)

http://www.ijmp.jor.br

V. 8, n. 3, July - September 2017

ISSN: 2236-269X

DOI: 10.14807/ijmp.v8i3.619

Using spreadsheet calculations, 70 hours are needed to unload an 8000TFE vessel, transfer the containers by train to Ashdod, and load them on other vessels (Table 5). If it is 4000TFE vessel, it will need ten voyages and 39 hours to make the transfer from Eilat to Ashdod.

Table 5: Time needed to transfer 8000 TFE from Eilat (Red Sea) to Ashdod (Mediterranean Sea)

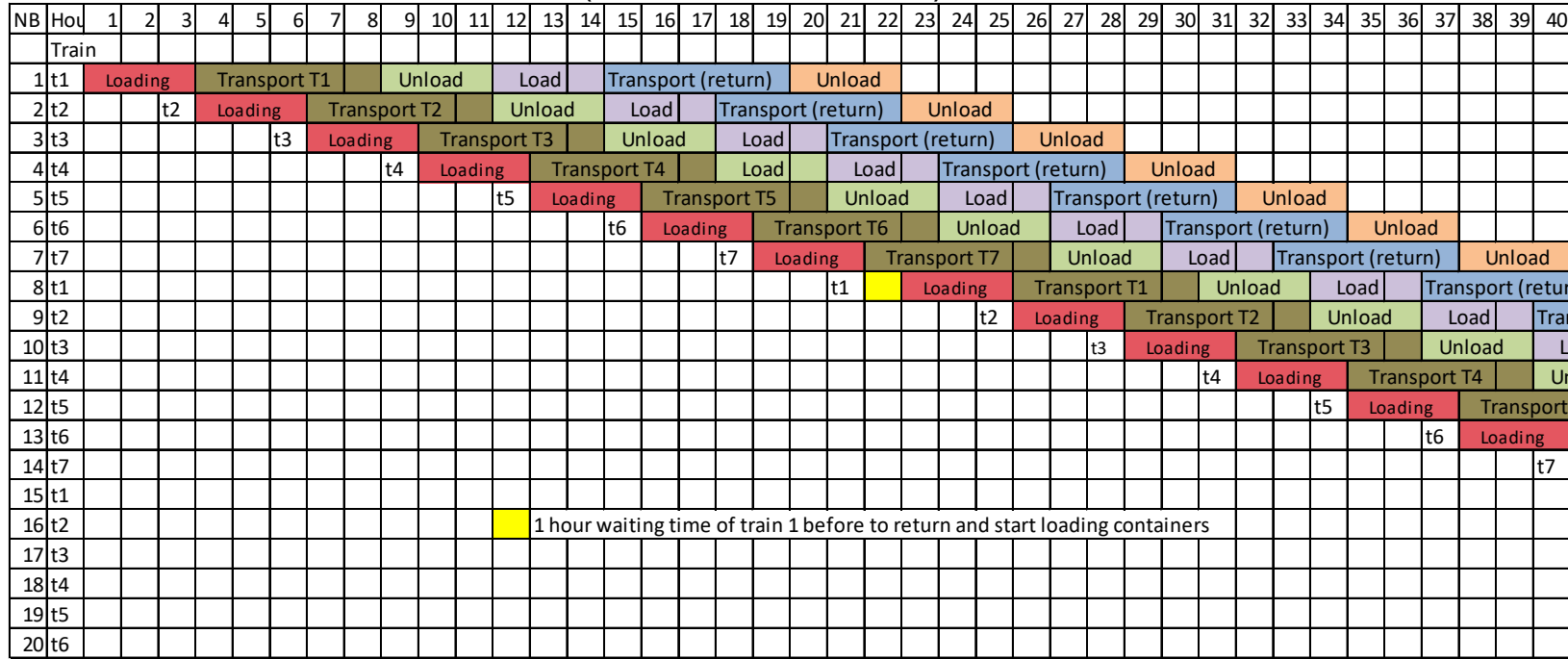

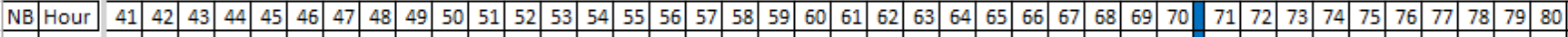

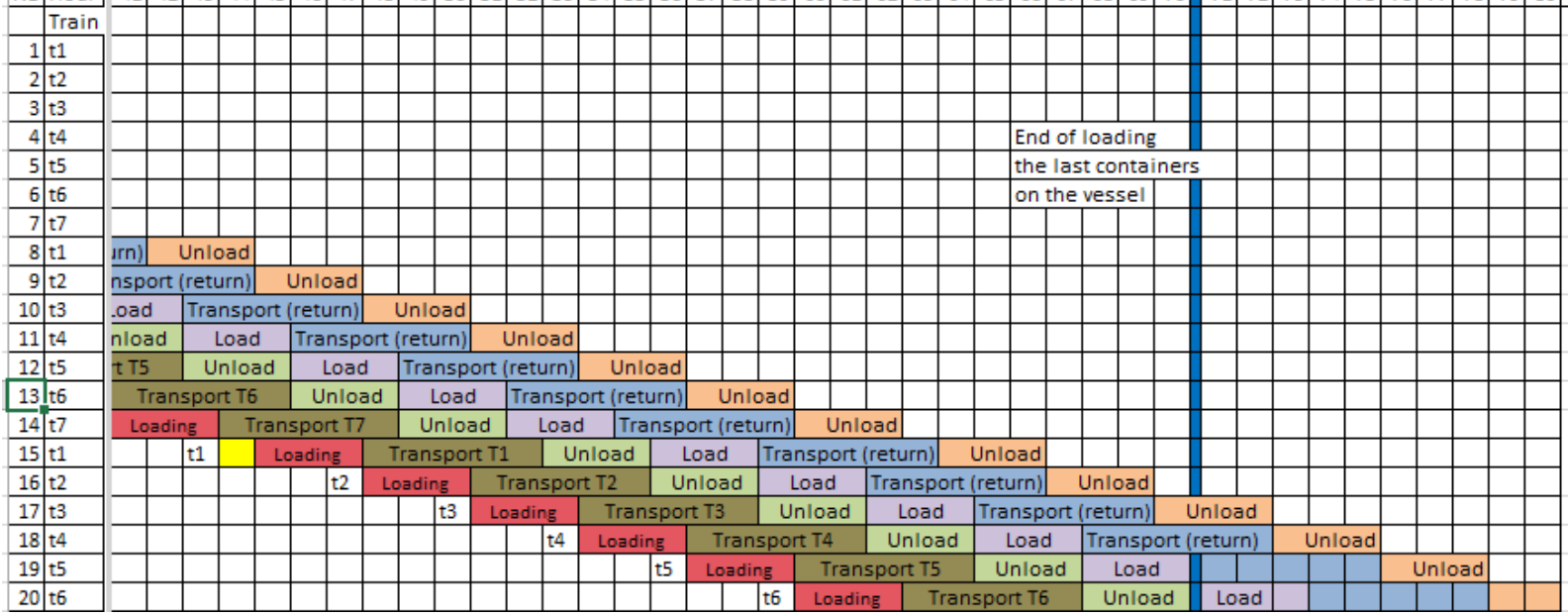

\subsubsection{Capacity estimation of Red-Med Railway}

Assuming that there are two ways to avoid accident risks and to facilitate traffic coordination, we considered 10 minutes between each voyage. In 24 hours, 144 voyages could be scheduled. A train with 100 wagons transports 400 TFE containers. In 24 hours 57,600 containers or $20,736,000$ per year could be transferred from one cost to another.

Is this capacity enough to compete with the Suez Canal? The number of containers traversed the Suez Canal in 2013 was 38,162,272 TFE northbound and 
DOI: 10.14807/ijmp.v8i3.619

southbound; one way, would be $50 \%$ of this quantity $19,081,136$ rounded to $20,000,000$. Theoretically, the RED-MED railway could replace the Suez Canal.

\subsubsection{How big should be the port of Eilat and Ashdod to replace the Suez} Canal?

The 20,000,000TFE containers are equivalent to 2,500 vessels having 8,000TFE each. Considering that each vessel requires 62 hours to be unloaded, 2500 vessels need 155,000 hours. Assuming that the port is working 360 days a year, 17.69 rounded to 18 places or berths are required to load and unload vessels in the port. To handle 40 million containers (20 million each way), 40 berths are needed. A port with this capacity is considered a very large. For example, in 2013 the maximum traffic of containers was in the Port de Shenzhen (China) followed by the port of Singapore with traffic of 33 million and 32 million containers respectively. Furthermore, the Port of Singapore has 59 berths for container traffic (Table 6).

Clearly, to be an alternative to the Suez Canal, the Red-Med railway should be connected to two ports (Eilat and Ashdod) larger than the biggest port in the world. At present, the port of Ashdod's capacity is 1.3 million TFE. On the other side, the port of Eilat is a small one with 150,000 TFE, a 12-metre water depth and, because of its location, limited growth potential. Furthermore, the railway should be double-tracked and reserved totally for freight transportation, which is different to the project's scope that foresees a double track for freight and passenger transportation. 
INDEPENDENT JOURNAL OF MANAGEMENT \& PRODUCTION (IJM\&P)

http://www.ijmp.jor.br

v. 8, n. 3, July - September 2017

ISSN: 2236-269X

DOI: 10.14807/ijmp.v8i3.619

Table 6: Annual traffic in millions of TFE sorted by the important ports in the World

\begin{tabular}{|c|c|c|c|c|c|c|c|}
\hline Rank & Ports & Countries & 2015 & 2013 & 2012 & 2011 & 2010 \\
\hline 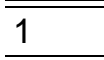 & Port of Shenzhen & China & 24,205 & 533,617 & 32,529 & 31,739 & 29,069 \\
\hline 2 & Port of Singapour & Singapore & 30,922 & 232,240 & 31,649 & 29,937 & 728,430 \\
\hline 3 & Port of Shanghai & China & 36,537 & 723,278 & 22,940 & 22,570 & 22,509 \\
\hline 4 & Port of Hong Kong & China & 20,073 & 322,352 & 23,117 & 24,384 & 423,699 \\
\hline 5 & Port of Busan & South Korea & 19,467 & 717,686 & 17,046 & 16,184 & 14,157 \\
\hline 6 & Port of Ningbo-Zhoushan & China & 20,627 & 717,351 & 15,670 & 14,510 & 13,144 \\
\hline 7 & Port of Tsingtao (Qingdao) & China & 17,436 & 15,520 & 14,503 & 13,020 & 12,012 \\
\hline 8 & Port of Canton (Guangzhou) & China & 17,590 & 15,309 & 914,743 & 314,260 & 12,550 \\
\hline 9 & Port of Jebel Ali (Dubaï) & E Arab Union Emirates & 15,592 & 213,641 & 13,270 & 13,000 & 11,600 \\
\hline 10 & Port of Tianjin & China & 14,111 & 13,010 & 12,300 & 11,580 & 10,080 \\
\hline 11 & Port of Rotterdam & Pays-Bas & 12,234 & 411,621 & 11,865 & 511,876 & 11,145 \\
\hline 12 & Port of Dalian & China & & 10,860 & 08,060 & 6,400 & 5,242 \\
\hline 13 & Port Klang (Kuala Lumpur) & alaysia & & 10,350 & 010,000 & 09,603 & 8,870 \\
\hline 14 & Port of Kaohsiung & T Taiwan & & 9,937 & 9,781 & 9,636 & 8,871 \\
\hline 15 & Port of Hambourg & Germany & 8820 & 9,302 & 8,863 & 9,014 & 7,896 \\
\hline 16 & Port of Anvers & Belgium & 9,653 & 8,578 & 8,635 & 8,664 & 8,468 \\
\hline
\end{tabular}

On http://fr.wikipedia.org/wiki/Liste_des_plus_grands_ports_\%C3\%A0_conteneurs

To simplify the calculation, we made an assumption that the ports of Eilat and Ashdod are working 24 hours a day, 7 days a week, and 365 days a year. This is different to present working conditions; for example, the port of Eilat works six days a week (Saturdays are off) (Unishiping, 2016). In addition, the working hours are: in winter from 0600-1400hrs and 1530-2300hrs; in summer from 0530-1330hrs and 1600-2300hrs.

\subsubsection{How many trains should the Red-Med railway have to be an alternative to the Suez Canal?}

In section 2.2.4, the consideration was that to be an alternative to the Suez Canal, the Red-Med railway should conduct a train every 10 minutes. A train takes 22 hours to cycle for another load. Therefore, $22 \times 6=132$ locomotives and 13,200 wagons need to be in operation.

In conclusion, the Red-Med railway project could be an alternative to the Suez Canal but not with the initial scope. The port of Eilat and Ashdod should be expanded to be as large as the largest port in the world. In addition, a double track should be reserved to carry the freight transportation. Again, this is different from the 
INDEPENDENT JOURNAL OF MANAGEMENT \& PRODUCTION (IJM\&P)

http://www.ijmp.jor.br

V. 8, n. 3, July - September 2017

ISSN: 2236-269X

DOI: 10.14807/ijmp.v8i3.619

initial project scope considering a double track for freight and passenger transportation.

\section{THE COST COMPETITIVELY OF THE TRANSPORTATION THROUGH THE RED-MED RAILWAY}

In this section, the cost to transfer a TFE container by Red-Med railway will be estimated and compared to Suez Canal route cost. Due the lack of information related to unloading 8000 TFE vessels in the Port of Eilat, loading on to 400 TFE trains, transporting the load $354 \mathrm{~km}$ to Ashdod, and loading on to vessels waiting in Ashdod, we have made reverse calculations by estimating the cost to transfer an 8000 TFE vessel through the Suez Canal.

The transfer time is rounded up to 24 hours (a day) from the transfer time (22 hours) estimated previously (section 3.1). The cost is: the charterage of one vessel at the rate 45,000USD/per day, plus the ship's operating cost, which is around 23,000USD, plus the Suez Canal toll, which is around 550,000USD, for an 8000TFE vessel with 60 per cent of load factor (NORDQUIST, 2013; LEE, 2013). The total will be 628,000 USD or 78,5 USD per container.

\subsection{The unloading and loading cost}

The discharge cost is considered one of the performance indicators of the port and there is a lack of empirical and comparative academic studies on time-related port performance indicators in general. The discharging cost was evaluated by (MOGHADAM; NOORI, 2011) 5,3GBP / container in 2010; considering a five percent (5\%) price increase, in 2015 the cost would be approximately 10USD / container. In Canada, the cost to load or unload a container is between 100 and 150 CAD equivalent to 80 and 120 USD, depending on the port (FROST; ROY, 2008).

Considering the GDP of Israel, Canada, and Iran, it appears that 10USD is too low and 80USD is too much. For this study, we considered 50USD for loading and unloading a container. To discharge or to charge 8000 TFE vessels would cost 400,000 USD. The discharging cost is a result of an average container handling time, crane productivity, and gang productivity. This kind of metric is collected by shipping lines, e.g. Maersk with its Daily Maersk Efficiency Ranking (HONG et al., 2013). 


\subsection{The train transportation cost}

The average cost to transport a container by train is difficult to estimate because there is many characteristics and services that could be included or excluded to affect the price. Consequently, for example, the British railway recommends hiring a third party logistic service to manage the transport service. To estimate the price to transport a container, we chose the website of the New Zealand Railway: Kiwi Railway http://www.kiwirailfreight.co.nz/pricing.aspx.

The distance between Christchurch and Dunedin is comparable to the distance between Eilat and Ashdod. The price on March 11, 2015, was 805NSD, which is equivalent to 589USD. Considering that the GDP per capita is $15 \%$ more in New Zealand compared to Israel (WORLBANK, 2016), the 589USD cost is reduced by $15 \%$, leaving the price at 515USD. This price is for the transportation of one container. Considering one third of the 515USD (171.7USD rounded up to 175USD), the cost to transport 8000 TFE containers from Eilat to Ashdod will be $1,400,000$ SD.

Comparing this result to data provided by VERNY and GRIGENTIN (2009) related to their study concerning container shipping on the Northern Sea route versus the Trans-Siberian Railway and the Suez Canal route, they found that the railway route is $30 \%$ more expensive. Consequently, the transfer of one container from Eilat to Ashdod through the Red-Med railway could be 78,5USD $\times 1.3=$ 102USD. Therefore, a 400 TFE train would cost 40,800USD; the cargo of 8000 TFE would cost 816,000USD.

In conclusion, to transfer 8000 TFE vessel containers from Eilat to Ashdod could cost 400,000USD $+1,480,000$ USD $=1,880,000$ USD. Compared to the cost of 628,000 USD to transfer via the Suez Canal, using the Red-Med railway will cost three times more.

\section{CONCLUSION}

Theoretically, the Red-Med railway could be an alternative to the Suez Canal for the container transportation. The criteria of the transit time and the cost was discussed in this paper. The main results were: (i) concerning to the transit time, the Red-Med railway could compete the Suez Canal in the case of 4,000 TFE Vessels, but (ii) for a the transfer cost, a TFE container unloaded from a vessel in Eilat, 
loaded on a train, transferred to Ashdod, and loaded on another vessel would cost approximately three time more than transit through the Suez Canal.

The cost will be also three times more than the Suez Canal for a transfer from Ashdod to Eilat. This conclusion indicates that the Suez Canal has the advantage as far as costs are concerned. However, other concerns, such as the security in the Suez Canal and the risk of its shutdown, must be considered. With a turbulent situation in Egypt and the increase of the terrorist attacks in the region as shown in this paper, a shutdown of the Suez Canal cannot be excluded.

In this situation, the Red-Med railway becomes vital for maritime transport. Additionally, it would compete with the route around the Cape of Good Hope. The cost of conveying a container along the Red-Med railway would not prohibitive, despite the fact that the operational costs of the Cape of Good Hope line can be relatively high.

In effect, to be a complete alternative to the Suez Canal in case of its closing, the Red-Med should be able to transfer around 20,000,000 TFE in each direction. Logistically, it is possible, but the infrastructures in the ports of Eilat and Ashdod should be extended to become comparable to the largest ports in the world. This constraint leads to nuance the statement: the Red-Med could be an alternative to the Suez Canal.

Therefore, the Red-Med could be an alternative for a certain percentage, for example, a fraction of $20 \%$ or $30 \%$ of the traffic. In a future research, the rate or the percentage that could assure the viability of Red-Med railway as an alternative to the Suez Canal for container transport could be determined optimally.

These conclusions are supported by a detailed analysis of container ship schedules with some assumptions about: the size of vessels, the average speed of the trains, the cost to load and unload containers on the vessels, and the working time of the ports of Eilat and Ashdod (24 hours a day, 7 days a week, 365 days a year). The reality could be different. All the assumptions are indicated clearly to allow verification, calculation, and adjustment.

It is important to mention that the Suez Canal is expected to see several improvements with a recent decisions made by the Egyptian Suez Canal Authority, 
so that it may accommodate the increasing influx of containers between Asia and Europe.

We recognize, however, that this research has certain limitations. First, as the economic environment is continuously evolving, any results based on calculations are subject to change. The various expenses contributing to the general cost of exploiting the Red-Med railway are linked directly to independent external factors (the cost of the use of the infrastructure in the ports, a barrel of oil, political instability, security in Sinai Peninsula, etc.).

Second, all this discussion rests upon complex, uneven, and uncertain variables whose eventual outcome remains beyond our knowledge: terrorist activity and political arrangements, instability in Egypt, etc. Due to the paucity of reliable results on this subject, other qualitative and quantitative studies of container transport via other Route are doubtless necessary.

\section{REFERENCES}

AMEDEO, F.; NODÉ-LANGLOIS, F. (2009) Alstom et la SNCF à l'offensive en Russie. Le Figaro [Online]. Available:

http://www.lefigaro.fr/societes/2009/03/31/04015-20090331ARTFIG00250-alstom-etla-sncf-a-I-offensive-en-russie-.php [Accessed March 15, 2017].

ANONYMOUS (2012) Red-Med railway pipe dream. Port Strategy: insight for senior port executives [Online].

DUCRUET, C.; ITOH, H.; MERK, O. (2014) Time Efficiency at World Container Ports. In: FORUM, I. T. (ed.). OECD.

\section{EL-SHARKAWY. (2017) Suez Canal Info.}

http://www.elsharkawygroup.com/scanal.html [Online]. Port Said - Egypt: ElSharkawy Group shipping \& Trading. [Accessed March 15, 2017].

FROST, J.; ROY, M.-A. (2008) Étude sur les opérations potentielles de transbordement de conteneurs selon une structure en étoile pour le transport maritime de marchandises (à courte distance) dans l'Est du Canada In: CPCS. (ed.). Canada http://www.bv.transports.gouv.qc.ca/mono/1006999.pdf.

GRADU, Y. (1977) Is the Israeli Negev a viable alternative to the Suez Canal? Geoforum, n. 8, p. 29-32.

HONG, Z.; MERK, O.; NAN, Z.; LI, J.; MINGYING, X.; WENQING, X.; XUFENG, D.; JINGGAI, W. (2013) The Competitiveness of Global Port-Cities: The case of Shanghai - ChinaOECD Regional Development Working Paper [Online]. Available: http://www.oecd-

ilibrary.org/docserver/download/5k3wd3bnz7tb.pdf?expires=1425950800\&id=id\&acc name=guest\&checksum=608DCECA0BAABD31A3F589CEA8422D35. 
INDEPENDENT JOURNAL OF MANAGEMENT \& PRODUCTION (IJM\&P)

http://www.ijmp.jor.br

v. 8, n. 3, July - September 2017

ISSN: 2236-269X

DOI: 10.14807/ijmp.v8i3.619

IMF. (2017) Exchange Rate Archives by Month [Online]. International Monetary Fund. [Accessed March 15 2017].

ISRAELI-GOVERNMENT (2012) Cabinet Approves Construction of a Tel AvivEilat Railway Line In: PRIME-MINISTER'S-OFFICE (ed.). Tel-Aviv Briefing Room.

LAKHAL, S. (2017) Towards a framework for a resilient supply chain in a turbulent environment: a review of its drivers. Int. J. Automation and Logistics. Inderscience http://www.inderscience.com/info/ingeneral/forthcoming.php?jcode=ijal

LEE, S.-W. (2013) Benefits and Riskof the Northern Sea Route to the Nort Pacific The Regulation of Continental Shelf Development: Rethinking International standards. Leiden [etc.] : Nijhoff.

LETH. (2017) Northbound Convoy [Online]. Oslo, Norway: LETH Agencies. Available: http://lethagencies.com/egypt/transit-guide-egypt/northbound-convoyegypt\#arrivallimitnorth [Accessed March 15, 2017].

LEVITT, J. (2014) Israel-China Alliance Moves Forward With \$2 Billion 'Red-Med' Freight Rail Link Alternative to Suez Canal. Algemeiner, March 24, 2014 [Online].

MATHIOT, C. (2009) Fret ferroviaire: Devedjian a l'esprit tortue. Liberation

Economie [Online]. Available: http://www.liberation.fr/economie/2009/10/14/fretferroviaire-devedjian-a-l-esprit-tortue_587577

MOGHADAM, M. K.; NOORI, R. (2011) Cost Function Modelling for Semi-automated SC, RTG and Automated and Semi-automated RMG Container Yard Operating Systems. International Journal of Business and Development Studies, n. 3, p. 85-122.

NORDQUIST, M. H. (2013) The regulation of continental shelf development: rethinking international standards, Charlottesville, VA, Center for Oceans Law and Policy.

NOTTEBOOM, T. E. (2011) In search of routing felxibility in international shipping: the cape route as an aleternative to the suez canal In: NOTTEBOOM, T. (ed.) Current issues in shipping ports and logistics, Brussels Universiteit Antwerp, University Press Antwerp.

NOTTEBOOM, T. E. (2012) Towards a new intermediate hub region in container shipping? Relay and interlining via the Cape route vs. the Suez route. Journal of Transport Geography, n. 22, p. 164-178.

RFI. (2014) De la Chine à l'Espagne, la plus longue liaison ferroviaire au monde. transport [Online]. Available: http://www.rfi.fr/economie/20141206-train-fretmarchandises-chine-espagne/ [Accessed March 15, 2017].

SCHLEGEL, B. (2013) The Land and the Bible: A Historical Geographical Companion to the Satellite Bible Atlas. In:

HTTP:/MWW.BIBLEPLACES.COM/ATLAS/THE\%20LAND\%20AND\%20THE\%20BI BLE.PDF (ed.).

SCOTT, E. (2014) China's Silk Road Strategy: A Foothold in the Suez, But Looking To Israel. China Brief [Online], 14. Available:

http://www.jamestown.org/programs/chinabrief/single/?tx_ttnews\%5Btt_news\%5D=4 2943\&cHash=9508d3a24834c6900c87914be9559460 [Accessed March 01, 2017]. 
TROCHE, G. (2005) High-speed rail freight Sub-report in Efficient train systems for freight transport In: GROUP, K. R. (ed.). Stockholm 2005: KTH, Centre for Railway Technology.

UNISHIPING. (2017) Unishiping Israel: port of Eilat [Online].

http://www.unishipping.co.il/eilat.html. [Accessed May 13, 2017].

VERISK. (2015) Egypt: Terrorist attacks increasing. Map of the week [Online].

VERNY, J.; GRIGENTIN, C. (2009) Container shipping on the Northern Sea Route. Int. J.Production Economics, n. 122, p. 107-117.

WIKIPIDIA (ed.) (2017) Rail speed limits in the United States.

WORLBANK. (2017) GDP per capita (current US\$) [Online].

http://data.worldbank.org/indicator/NY.GDP.PCAP.CD: World Bank. Available:

http://data.worldbank.org/indicator/NY.GDP.PCAP.CD [Accessed May 13, 2017]. 